\title{
The Development and Evolution of Marxist Sociology since the Reconstruction of Chinese Sociology
}

\author{
Mingbo Zhang \\ Marxism School, Sichuan University, Chengdu,Sichuan,610207,China
}

\begin{abstract}
Sinicized Marxist sociology is the product of combining Marxism with Chinese practice and it is a sociological theory with Chinese characteristics. Since the reconstruction of sociology, in the great practice of socialism with Chinese characteristics, Deng Xiaoping, Jiang Zemin, Hu Jintao and Xi Jinping have vigorously pushed forward the process of Marxist sociology in China. They have combined with the development of China and have thoroughly studied the stability of Chinese reform and development using Marxist standpoint, viewpoint and method and gradually formed a Marxist sociology with Chinese characteristics.

Keywords: sociology, reconstruction, Marxist Sociology
\end{abstract}

\section{Introduction}

Marx is not only a philosopher, but also a sociologist, he and Durkheim and Weber as one of the three classical sociologies, Marx pioneered Marxist sociology and Durkheim's empirical sociology, Weber's Humanities and Social Sciences Constitute the three main schools of sociology. Since the introduction of Marxism in China, Mao Zedong, Deng Xiaoping, Jiang Zemin, Hu Jintao and Xi Jinping have all tried to combine the Marxist theory with the practice of Chinese revolution, construction and reform and push forward the process of Marxism in China. The process of Marxism sinicization is also the process of sinicization of Marxist sociology. It is with the practice of Chinese revolution, construction and 
reform that Marxist sociology with Chinese characteristics has been gradually formed on the land of China.

\section{The introduction of Marxist sociology in China}

Although Marx and Engels did not explicitly say that they are sociologists, the writings of Marx and Engels contain very rich sociological thoughts. They have great influence on the social nature, social constitution, social contradiction, social dynamics, social form and the analysis of social law is based on the scientific materialist conception of history, which is much more profound than that of the western sociology represented by Comte. Lenin once explicitly pointed out that "Marx also overthrew the kind of the society as the Executive will (or according to the social will and the will of the government, anyway, the same) casually change, accidental and change, mechanical individual combination The concept of the socio-economic formation as a sum of the relations of production is proved, and the development of this form is proved to be a natural historical process, and for the first time put sociology on the basis of science. Lenin, Plekhanov, Bukharin have affirmed the Marx and Engels's sociological thinking, but because of Stalin critically criticized Bukharin, and Bukharin that historical materialism is in fact Marxist sociology, Resulting in Marx and Engels's sociological thought affected and suppressed. Today, Stalin's criticism of Bukharin is unreasonable, that the historical materialism belongs to sociology is no problem, and we should see from the Marx and Engels began, Marxist sociology of thinking is evolving, although Period, but the Marxist sociological thinking with the development of practice and the times. So, what is Marxist sociology? "Marxist sociology is Marx, Engels began to historical materialism as the theoretical basis and guiding ideology of the sociology of the term including Marx, Engels himself and his successor's sociological thought, social doctrine, and contemporary scholars With the Marxist stand, viewpoints and methods described by the sociological theory, doctrine, etc. "

The October Revolution brought the Marxism to China, which also contained the Marxist sociological thought. Since the introduction of Marxism in China, the Marxist sociology has also begun the process of Chinese-style transformation. The early leaders of the Chinese Communist Party actively propagated Marxism to the Chinese people. They accepted the theory of materialist conception of history, realized the decisive effect of material production on social development, realized that the masses were the real driving force of historical development and accepted class struggle as the direct driving force of social development. The establishment of Marxist sociology of the basic framework system; committed to the spread of Marxist sociology, and focus on the cultivation of social science talent. "Li $\mathrm{Da}$ is in the field of Marxist sociology research made significant achievements in sociology, one of his ideas mainly reflected in the" modern sociology "a book, which is from the historical materialist system of Marxist society of a complete exposition of Marxist society Comrade Mao Zedong is a strong Marxist and the Chinese revolution and construction of the actual 
combination, mainly in Mao Zedong on China's social structure, class accurate analysis, Mao Zedong attaches great importance to social investigation, is on the basis of a large number of investigations, Mao Zedong profoundly analyzed the nature of China's society, the situation of various classes, pointed out the object of the revolution, relying on the strength, the revolutionary stage and so on, to find the success of the Chinese revolution. After the founding of the People's Republic of China, Mao Zedong attached great importance to the study of the contradictions of socialism in the light of the development and changes in the construction of new China, and stressed the need to correctly handle the two contradictions of different natures. In his study of socialist construction, he proposed to properly handle the ten relations.

\section{The disruption and reconstruction of Chinese sociology}

Sociology into China after the great development, but soon after the founding of new China, university faculty adjustment, the National College of sociology was revoked, sociology teachers are transferred to other disciplines to develop, from sociology in China Development has been seriously affected. On March 30, 1979, Comrade Deng Xiaoping made important speeches on the "Four Cardinal Principles" at the party's theoretical work retreat. He stressed that "the study of politics, law, sociology and world politics, " In the spirit of the Central Committee, Chinese sociology to achieve rapid recovery and reconstruction, professional, department, research institutions, Societies have become more and more accepted by the community, recognition and appreciation. However, we regret that the Chinese sociological community in the practice of reform and opening up since the formation of the Chinese Marxist sociological research and mining is not enough.

\section{The new development of Marxist sociology since the reconstruction of Chinese sociology}

Since the reconstruction of sociology, the Chinese Communist Party has led the people of all nationalities in the country to closely integrate Marxist sociological theories with the great practice of China's reform and opening-up, push the localization of Marxist sociology to a new stage and gradually form a new period Marxist Sociology. This is mainly reflected in Deng Xiaoping, Jiang Zemin, Hu Jintao, Xi Jinping characteristics of socialism with Chinese characteristics at different stages of the characteristics of China's social nature, social structure, social development, social reform, social construction and other aspects of the brilliant exposition, these discourse runs through Marx The position and perspective of the Chinese people, the profound analysis of the social situation in China, the accurate grasp of the direction of China's social development, the great liberation of productive forces and the development of productive forces, and 
continuously improve the people's material and cultural life, promoting healthy operation of Chinese society and Coordinated development, enhance China's international status and influence.

Deng Xiaoping, the chief architect of China's reform and opening-up policy, pushed forward the discussion of the question of truth standards, promoted ideological liberation, opened economic construction as the centre, unceasingly liberated the productive forces and developed the productive forces, promoted the continuous improvement of the Chinese people's living standard, And promoted the continuous enhancement of China's overall national strength. At the same time, Deng Xiaoping directly promoted the reconstruction of Chinese sociology, his sociology "need to make up classes" call, a strong impetus to the reconstruction of Chinese sociology, to promote the Marxist sociology in China to achieve new development. Comrade Deng Xiaoping has a wealth of sociological thinking, the famous sociologist Zheng Hangsheng stressed that "Deng Xiaoping Theory contains a wealth of Chinese characteristics with the sociological thinking" Deng Xiaoping strongly promoted the development of Marxism in China, mainly in: Socialism is the essence of the liberation of productive forces, the development of productive forces, the elimination of exploitation, the elimination of polarization, and ultimately realize the common prosperity of the profound reveal; whether it is conducive to the development of productive forces, is conducive to enhance the development of socialism, Whether the overall national strength is conducive to raising the people's living standards of the "three is conducive to" the standard put forward; both material and spiritual civilization should be grasped with both hands should be hard to emphasize; socialism and the market economy is not antagonistic.

Under the wise leadership of Jiang Zemin, China has successfully responded to various challenges and successfully pushed forward the great process of reform and opening up initiated by Deng Xiaoping. In the course of reform and openingup, Jiang Zemin, the leader of the Party, Defending Deng Xiaoping's theory of socialism with Chinese characteristics, gradually establishing a market economy system, closely managing the country by law and by virtue, and scientifically dealing with reform, development and stable relations, effectively promoted the development of productive forces and reformed the relations of production in a timely manner In the development of productive forces do not meet the aspects and links. Jiang Zemin also closely combined with the international and domestic situations to strengthen the party building. He has been deeply thinking about and exploring the important question of "what kind of party should be built and how to build the party" and put forward the important thinking of the "three represents" Our Party has won the support of the people because our party has always represented the development requirements of China's advanced productive forces in various historical periods of revolution, construction and reform, representing the direction of the advancement of Chinese culture, representing the majority of the Chinese people. Fundamental interests, and through the formulation of the correct line, principles and policies, in order to achieve the fundamental interests of the country. 
Since the 16th National Congress of the Communist Party of China (CPC), Comrade $\mathrm{Hu}$ Jintao has profoundly analyzed the stage of China's social development in the new era, the contradictions it faces, the outstanding problems to be solved, and profoundly answered "what is development and how to develop" according to the development and changes in international and domestic situations. , "What is a harmonious society, how to build a harmonious society" and other major issues, put forward the scientific concept of development, made a major decision to build a harmonious society. The scientific outlook on development emphasizes that "the first essence is development, the core is people-oriented, the basic requirements are comprehensive, coordinated and sustainable, the fundamental method is to take into account" harmonious society, "democracy and rule of law, fairness and justice, honesty, Stability and order, harmony between man and nature. "

Since the 18th National Congress of the Communist Party of China (CPC), Xi Jinping has led the people of all nationalities to hold high the great banner of socialism with Chinese characteristics and deepened the overall layout of the "five in one" of economic, political, cultural, social and ecological construction, and gradually formed a comprehensive Building a well-off society, comprehensively deepening the reform, comprehensively administering the country according to law, and comprehensively and rigorously managing the party's "four comprehensive" strategic layout, making a major judgment on China's economic development entering a new normal, and proposing innovative, coordinated, green, open and shared "Five new development concept", and further promote the supply side of the structural reform, and continuously meet the people's growing material and cultural needs of life, steady poverty alleviation work steadily and so on. All these have profoundly embodied that Comrade Xi Jinping always adhered to the people-centred development concept, embodied his deep theoretical foundation and way of thinking of Marxism, and it is the latest achievement of the combination of Marxist sociological thought and contemporary Chinese practice. From the concept of comprehensive development continue to draw nutrition, Chinese discourse system of Chinese characteristics will become increasingly clear.

\section{References}

[1] The Complete Works of Lenin (Volume 1). People's Publishing House pp.111, 1984

[2] The Development of Sociological Theory with Chinese Characteristics. China Renmin University Press pp.332, 2005

[3] Chen Guoqing, Li Jin. On the Sinicization of Marxist Sociology. Journal of Northwest University (Philosophy and Social Sciences Edition) 12(10), pp. 1820, 2007

[4] Selected Works of Deng Xiaoping (Volume II). People's Publishing House 9(6), pp.1801-181, 1994

[5] Deng Xiaoping. Theory and the Prosperity and Development of Sociology. Guangming Daily, 8(4), pp.85-87, 2014 